\title{
A comparison of short-term therapeutic efficacy between infliximab and tacrolimus for moderate to severe ulcerative colitis
}

\author{
HIROKAZU YAMAGAMI ${ }^{1, *}$, YU NISHIDA ${ }^{1}$, YASUAKI NAGAMI ${ }^{1}$, SHUHEI HOSOMI ${ }^{1}$, TOMOMI YUKAWA ${ }^{1}$, \\ KOJI OTANI ${ }^{1}$, FUMIO TANAKA ${ }^{1}$, KOICHI TAIRA ${ }^{1}$, NORIKO KAMATA ${ }^{1}$, TETSUYA TANIGAWA ${ }^{1}$, \\ MASATSUGU SHIBA $^{1}$, TOSHIO WATANABE ${ }^{1}$, YASUHIRO FUJIWARA $^{1}$ \\ ${ }^{1}$ Department of Gastroenterology, Osaka City University Graduate School of Medicine \\ 1-4-3, Asahimachi, Abeno-ku, Osaka, 545-8585 Japan
}

\begin{abstract}
Introduction. Both infliximab (IFX) and tacrolimus (Tac) are effective for inducing clinical remission in patients with ulcerative colitis (UC). However, no randomized study has addressed the relative efficacies of IFX and Tac for patients with moderate to severe UC. This study aimed to conduct a retrospective study on the relative efficacy of IFX and Tac in patients with moderate to severe UC, using an inverse probability of treatment weighting (IPTW) technique to adjust background factors statistically.

Methods. Between July 2009 and March 2016, data obtained from 122 patients with moderate to severe UC who were treated with either IFX $(n=58)$ or Tac $(n=64)$ were analyzed retrospectively. We compared the short-term therapeutic efficacy between the IFX group and Tac group using IPTW technique.

Results. The clinical remission rate at 14 weeks after treatment was $37.9 \%(22 / 58)$ in the IFX group and $50 \%(32 / 64)$ in the Tac group, respectively. The efficacy of IFX and Tac for clinical remission rate was not different according to univariate (Odds ratio [OR] 1.64, 95\% confidence interval [CI] 0.80-3.37 $P=0.18$ ) and multivariate analyses (OR 2.19, 95\% CI 0.85-5.61, $P=0.10$ ). After the background and confounders factors were adjusted by using IPTW based on propensity score, the efficacy of IFX and Tac for clinical remission rate was not differed statistically (OR, 1.483; 95\% CI, $0.581-3.785 ; P=0.409)$

Conclusion. IFX and Tac have equivalent short-term efficacies for induction in patients with moderate to severe UC.
\end{abstract}

Key words: infliximab; inverse probability of treatment weighting; remission rate; tacrolimus; ulcerative colitis.

\section{INTRODUCTION}

Ulcerative colitis (UC) is a disabling chronic remitting and relapsing inflammatory disorder of the large bowel. Treatment of UC has relied mainly on 5-aminosalicylates and corticosteroids. Patients with UC sometimes experience a flare during the course of their disease and are then treated with corticosteroids to induce remission. Corticosteroids are effective in inducing remission for most patients with moderate to severe UC; however, approximately $20-30 \%$ of cases are refractory or dependent on corticosteroid therapy [1-3].

Cyclosporine (CsA) and infliximab (IFX) are effective for inducing clinical remission in patients with moderate to severe UC $[4,5]$. A recent systematic review and meta-analysis showed no difference between the effectiveness of CsA and IFX when used as rescue agents in patients with steroid-refractory UC [6]. Tacrolimus (Tac), a calcineurin inhibitor that has a mechanism of action similar to CsA, also has therapeutic efficacy for moderate to severe UC $[7,8]$. Several retrospective studies showed IFX and Tac had equal efficacy for moderate to severe UC [9-11]. These studies were retrospective and therefore the background characteristics of the patients were not randomized. To the best of our knowledge, no randomized study exists that addresses the relative efficacies of IFX and Tac for patients with moderate to severe UC.

Recently, an inverse probability of treatment weighting (IPTW) method was developed to statistically adjust for background factors. IPTW reduces the influences of selection bias and potential confounding factors between groups, therefore making pseudo-randomization possible. The aim of this study was to conduct a retrospective study on the relative efficacy of IFX and Tac in patients with moderate to severe UC, using an IPTW technique.

\section{MATERIALS AND METHODS}

\section{PATIENTS}

Between July 2009 and March 2016, IFX or Tac was administered to 149 patients with moderate to severe ulcerative colitis in our hospital. The diagnosis of UC was based on clinical, 
endoscopic, and histopathological findings [12]. After reviewing their clinical records, we excluded the following patients from the analysis: 1) 18 patients with positive cytomegalovirus infection, and 2) 9 patients who had used IFX, Tac, or adalimumab within 2 months of the study. A total of 122 patients were reviewed retrospectively and their data were used to compare the short-term therapeutic efficacy between the IFX and Tac groups. This study was approved by the ethics committee of Osaka City University Graduate School of Medicine.

\section{MEDICAL TREATMENT}

IFX was used according to its label, that is, induction with $5 \mathrm{mg} / \mathrm{kg}$ at week 0,2 , and 6 , and when a clinical response was observed, maintenance treatment with $5 \mathrm{mg} / \mathrm{kg}$ every 8 weeks. Tac was orally administered at an initial dose of $0.05-0.1 \mathrm{mg} / \mathrm{kg} /$ day twice a day. The dosage was adjusted to achieve a whole blood trough level of $10-15 \mathrm{ng} / \mathrm{mL}$ during the initial 2 weeks and subsequently $5-10 \mathrm{ng} / \mathrm{mL}$. Tac was discontinued at week 13 because the use of Tac for more than 3 months has not been approved by the Japanese health insurance system. The selection of drug was made at the physicians' discretion.

\section{ASSESSMENT OF EFFICACY}

We compared the efficacy of IFX versus Tac for moderate to severe UC. The primary endpoint was clinical remission rate during the 14 weeks after initiation of IFX or Tac administration.

\section{DEFINITION}

The disease activity of UC was assessed using the partial Mayo score that performed as well as the full Mayo score when assessing clinical response in a prior clinical trial [13]. Active disease was defined as a partial Mayo score $>4$. Clinical remission was defined as a partial Mayo score was 0 or 1 [14] at week 14 without death due to UC attack before week 14, proctocolectomy before week 14 , or secondary alternative drug use such as corticosteroids before week 14 .

The steroid-refractory state was defined as patients who had active disease despite either intravenous prednisolone more than $1 \mathrm{mg} / \mathrm{kg} /$ day over at least one week, or oral prednisolone more than $30 \mathrm{mg} /$ day over at least two weeks. The steroid-dependent state was defined as patients who were either unable to taper prednisolone below less than $10 \mathrm{mg} /$ day without recurrent disease or had a relapse within three months of stopping prednisolone.

\section{STATISTICAL ANALYSIS}

Continuous variables were summarized with the median and interquartile range (IQR). The differences between clinical characteristics were compared using the chi-square test or Fisher's exact test for categorical variables and the Mann-Whitney $\mathrm{U}$ test for continuous variables. Univariate and multivariate logistic regression analyses were performed to identify factors associated with clinical remission at week 14 . The model included age, gender, history of flare, disease location, concomitant therapies, partial Mayo score, WBC, hemoglobin, albumin, and $\mathrm{C}$ reactive protein (CRP).

For each factors considered to have potential association with clinical remission, the odds ratio (OR) with its $95 \%$ confidence interval $(95 \% \mathrm{CI})$ were calculated. Factors with $P<0.3$ by univariate analysis and known risk factors of clinical remission (CRP, albumin, hemoglobin, disease location, and concomitant therapies) were further analyzed in the multivariate analysis. Logistic regression was used to create propensity scores (PS) from the baseline characteristics as follows: age, gender, history of flare, disease location, concomitant therapies, partial Mayo score, WBC, hemoglobin, albumin, CRP, and response to corticosteroids.

In this study, the background and confounders factors were adjusted by using IPTW based on PS. Patients were then weighted by the inverse of the probability of receiving the treatment that they actually received. The validity of the model was assessed by estimating the area under the receiver operating characteristics curve using c-statistics.

A $P$-value less than 0.05 was defined as statistically significant. Statistical analyses were performed with SPSS software version 23.0 for Windows (SPSS Inc., Japan) and EZR (Saitama Medical Center, Jichi Medical University), which is a graphical user interface for R (The R Foundation for Statistical Computing, version 2.13.0). More precisely, it is a modified version of $\mathrm{R}$ commander (version 1.6-3) that includes statistical functions that are frequently used in biostatistics. 


\section{RESULTS}

\section{BASELINE CHARACTERISTICS}

A total of 122 patients were analyzed in this study. Fifty-eight patients were treated with IFX and 64 patients were treated with Tac. The clinical baseline patients' characteristics of the IFX and Tac groups are shown in Table 1. At the baseline, patients in both treatment groups were matched for epidemiologic characteristics, age, sex, disease location, and response to corticosteroids, except for concomitant corticosteroid therapies and history of flares. The patients with a first attack were 3 (5.2\%) and $17(26.6 \%)$ in the IFX and Tac group, respectively $(P=0.001)$. The patients with concomitant corticosteroid therapies were 26 (44.8\%) and 45 (70.3\%) in the IFX and Tac group, respectively $(P=0.006)$. No differences between the groups were found in clinical disease activity using the partial Mayo score. The median partial Mayo score at base line was 7 (IQR, 6-7) in the IFX group vs. 6 (IQR, 3-9) in the Tac group $(P=$ $0.600)$. In the laboratory data, hemoglobin was not different between the groups; however, the WBC, serum albumin and CRP were different. The median level of WBC was $6400 / \mu \mathrm{L}$ (IQR, 4800-8250) in the IFX group $v s .8550 / \mu \mathrm{L}$ (IQR, 6150-11300) in the Tac group $(P<0.001)$, serum albumin was $3.7 \mathrm{~g} / \mathrm{dL}$ (IQR, 3.4-4.1) in the IFX group $v s$. $3.2 \mathrm{~g} / \mathrm{dL}$ (IQR, 2.6-3.6) in the Tac group $(P<$ 0.001 ), and serum CRP was $0.3 \mathrm{mg} / \mathrm{dL}$ (IQR, $0.1-0.8)$ in the IFX group $v s .2 .6 \mathrm{mg} / \mathrm{dL}$ IQR, $0.55-7.22)$ in the Tac group $(P<0.001)$.

Table 1

Baseline characteristics of study subjects

\begin{tabular}{|c|c|c|c|}
\hline & Infliximab $(\mathrm{n}=58)$ & Tacrolimus $(\mathrm{n}=64)$ & $P$ value \\
\hline Age (year) & $42.2(30.4-52.2)$ & $37.9(27.6-51.4)$ & 0.566 \\
\hline Sex & & & 0.204 \\
\hline Female, n (\%) & $33(56.9 \%)$ & $28(43.8 \%)$ & \\
\hline Male, n $(\%)$ & $25(43.1 \%)$ & $36(56.3 \%)$ & \\
\hline History of flare & & & 0.001 \\
\hline First attack & $3(5.2)$ & $17(26.6)$ & \\
\hline Relapse & $55(94.8)$ & $47(73.4)$ & \\
\hline Location & & & 0.230 \\
\hline Left-sided colitis, $n(\%)$ & $20(34.5 \%)$ & $15(23.4 \%)$ & \\
\hline Pancolitis, n (\%) & $38(65.6 \%)$ & $49(76.6 \%)$ & \\
\hline \multicolumn{4}{|l|}{ Concomitant therapies } \\
\hline Corticosteroids, n (\%) & $26(44.8 \%)$ & $45(70.3 \%)$ & 0.006 \\
\hline Azathioprine, n (\%) & $19(32.8 \%)$ & $14(21.9 \%)$ & 0.222 \\
\hline \multicolumn{4}{|l|}{ Response to corticosteroids } \\
\hline Dependent, $\mathrm{n}(\%)$ & $29(50.0 \%)$ & $22(34.4 \%)$ & 0.099 \\
\hline Resistant, n (\%) & $19(32.8 \%)$ & $30(46.9 \%)$ & 0.140 \\
\hline Partial Mayo score (IQR) & $7(6-7)$ & $6(3-9)$ & 0.600 \\
\hline $\mathrm{WBC}(/ \mu \mathrm{L})$ & $64.0(48.0-82.5)$ & $85.5(61.5-113.0)$ & $<0.001$ \\
\hline Hemoglobin (g/dL) & $11.8(10.8-12.7)$ & $11.2(9.7-12.8)$ & 0.078 \\
\hline Albumin (g/dL) & $3.7(3.4-4.1)$ & $3.2(2.6-3.6)$ & $<0.001$ \\
\hline $\mathrm{CRP}(\mathrm{mg} / \mathrm{dL})$ & $0.3(0.1-0.8)$ & $2.6(0.55-7.22)$ & $<0.001$ \\
\hline
\end{tabular}

Values are median (IQR) or number (percentage).

CRP: C reactive protein, IQR: interquartile range.

\section{TREATMENT OUTCOMES AT 14 WEEKS}

The clinical remission rates at 14 weeks after treatment were $44.3 \%(54 / 122)$ in both IFX and Tac group, $37.9 \%(22 / 58)$ in the IFX group and $50 \%(32 / 64)$ in the Tac group, respectively. Univariate and multivariate analyses associated with clinical remission at week 14 are shown in Table 2 .
The lower partial Mayo score at base line was a predictive factor for clinical remission at week 14 (OR 1.44, 95\% CI 1.05-1.97 $P=0.024$ ). The efficacy of IFX and Tac for clinical remission rate was not different according to univariate (OR 1.64, 95\%CI $0.80-3.37 P=0.18)$ and multivariate analyses (OR 2.19, 95\% CI 0.85-5.61, $P=0.10$ ). Other factors including CRP, albumin, disease 
location, hemoglobin, concomitant therapies were not significantly related to clinical remission either.

In this study, baseline characteristics differed between both IFX and Tac groups. Therefore, we used the IPTW method to compare treatment outcomes. After IPTW, there were likely no differences in confounding factors in two groups. The propensity-weighted model was well calibrated (Hosmer Lemeshow test, $P=0.132$ ). The efficacy of IFX and Tac for clinical remission rate was not different statistically (OR, 1.483; 95\% CI, $0.581-$ 3.785; $P=0.409$ ) (Table 3).

Table 2

Univariate and multivariate analyses of predictive factors for clinical remission rate at 14 weeks after treatment

\begin{tabular}{|c|c|c|c|c|c|}
\hline & $\mathrm{n}$ & Crude OR $(95 \% \mathrm{CI})$ & $P$ value & Multivariate OR $(95 \% \mathrm{CI})$ & $P$ value \\
\hline Age & & $1.00(0.97-1.02)$ & 0.76 & & \\
\hline \multicolumn{6}{|l|}{ Sex } \\
\hline Female & $27(44.2 \%)$ & $1.00(0.49-2.04)$ & 1.00 & & \\
\hline Male & $27(44.2 \%)$ & 1.00 & & & \\
\hline \multicolumn{6}{|l|}{ History of flare } \\
\hline First attack & $9(45.0 \%)$ & $0.97(0.37-2.53)$ & 0.94 & & \\
\hline Relapse & $45(44.1 \%)$ & 1.00 & & & \\
\hline \multicolumn{6}{|l|}{ Location } \\
\hline Left-sided colitis & $14(40.0 \%)$ & $1.28(0.57-2.83)$ & 0.55 & $1.42(0.57-3.50)$ & 0.45 \\
\hline Pancolitis & $40(46.0 \%)$ & 1.00 & & 1.00 & \\
\hline \multicolumn{6}{|l|}{ Concomitant therapies } \\
\hline Corticosteroids & $33(46.5 \%)$ & $0.81(0.39-1.67)$ & 0.56 & $0.64(0.28-1.47)$ & 0.30 \\
\hline Azathioprine & $17(51.5 \%)$ & $0.67(0.30-1.49)$ & 0.33 & $0.61(0.26-1.47)$ & 0.27 \\
\hline \multicolumn{6}{|c|}{ Response to corticosteroids } \\
\hline Dependent & $25(49.0 \%)$ & $0.72(0.35-1.48)$ & 0.37 & & \\
\hline Resistant & $23(46.9 \%)$ & $0.83(0.40-1.73)$ & 0.63 & & \\
\hline Partial Mayo score & & $1.44(1.05-1.97)$ & 0.024 & $1.31(0.93-1.84)$ & 0.12 \\
\hline WBC & & $0.99(0.98-1.00)$ & 0.24 & & \\
\hline Hemoglobin & & $1.11(0.91-1.36)$ & 0.29 & $1.20(0.93-1.55)$ & 0.17 \\
\hline Albumin & & $0.87(0.49-1.54)$ & 0.64 & $0.51(0.21-1.26)$ & 0.14 \\
\hline CRP & & $1.03(0.95-1.13)$ & 0.45 & $1.03(0.93-1.15)$ & 0.56 \\
\hline \multicolumn{6}{|l|}{ Treatment } \\
\hline IFX & $22(37.9 \%)$ & $1.64(0.80-3.37)$ & 0.18 & $2.19(0.85-5.61)$ & 0.10 \\
\hline Tac & $32(50.0 \%)$ & 1.00 & & 1.00 & \\
\hline
\end{tabular}

OR: odds ratio, CI: confidence interval, CRP: C reactive protein, IFX: infliximab, Tac: tacrolimus.

Table 3

Propensity score weighted of the efficacy of IFX and Tac for clinical remission rate

\begin{tabular}{lcc}
\hline & OR $(95 \% \mathrm{CI})$ & $P$ value \\
\hline Unadjusted & $1.64(0.80-3.37)$ & 0.18 \\
Adjusted & $2.19(0.85-5.61)$ & 0.10 \\
IPTW & $1.483(0.581-3.785)$ & 0.409 \\
\hline
\end{tabular}

OR: odds ratio, CI: confidence interval, IPTW: inverse probability of treatment weighting.

\section{DISCUSSION}

In the present study, we demonstrated that IFX and Tac have a similar short-term therapeutic efficacy in patients with moderate to severe UC. There are no randomized controlled trials comparing IFX and Tac that can provide information about which salvage agents should be chosen for moderate to severe UC. CsA, a calcineurin inhibitor with a mechanism of action similar to that of Tac, is also a salvage agent for severe UC. The choice between CsA and IFX as salvage therapy for severe UC has been studied in several randomized controlled trials $[15,16]$. No difference was observed between CsA and IFX in efficacy for severe UC and the choice is primarily determined by patient and physician preference and local availability [3].

In this study, the criteria for choosing IFX or Tac was the physician's decision. In our hospital, the physicians tended to choose Tac for patients 
with severe UC who required hospitalization. IFX can be easily administered to both inpatients and outpatients. Conversely, Tac can only be easily administered to inpatients, because physicians have to collect blood samples from patients 48 hours after initial Tac treatment and change the dosage of Tac to achieve an ideal trough level. After initially adjusting the dose of Tac, physicians have to collect blood samples repeatedly to maintain an ideal trough level.

Low serum albumin levels, high serum CRP levels, and a high concentration of calprotectin in the feces are commonly used inflammatory markers that have been associated with the need for colectomy $[3,17]$. Patients who require hospitalization have a trend toward a lower serum albumin and higher CRP levels. In this study, although the partial Mayo score at initial administration of IFX or Tac was not different statistically, patients in the Tac group had statistically significantly lower serum albumin levels and higher serum CRP levels than the IFX group. Patients with low albumin levels and high CRP levels may be primary non-responders to IFX because rapid clearance of IFX was associated with lower serum albumin levels and higher CRP levels at baseline, and lower serum IFX concentration in the early weeks after initial IFX administration was associated with a lack of endoscopic response [18, 19]. It was acceptable that the levels of serum albumin were higher and CRP levels were lower at baseline in the IFX group than the Tac group in our retrospective study because the choice of agents was at the physicians' discretion.

There are a few retrospective studies that reported equivalent short-term therapeutic efficacy of anti-TNF agents and Tac in patients with moderate to severe UC. Yamamoto et al. [9] have reported that for 100 patients with moderate to severe UC, the clinical remission rate after 12 weeks was $28 \%$ and $40 \%$ in the anti-TNF agents and Tac groups, respectively. Serum albumin and CRP levels at baseline were not statistically different between groups. Nuki et al. [11] reported in their retrospective study of 46 patients with moderate to severe UC the clinical remission rate after 10 weeks was $76 \%$ and $67 \%$ in the IFX and Tac groups, respectively. They reported CRP levels at baseline were not statistically different between groups, but serum albumin levels were not discussed. Endo et al. [10] reported the clinical remission rate after 2 months was $68.8 \%$ and $55.3 \%$ in the IFX and Tac groups, respectively, in their retrospective study of 95 patients with steroid-refractory UC. They reported that serum albumin and CRP levels at baseline were significantly different between groups.

In the current study, serum albumin levels and CRP levels at baseline were statistically different between groups. Although a prospective randomized controlled trial is desirable to reduce selection bias and potential confounding factors between groups, we used an IPTW technique to reduce them in this study.

Our study had the following limitations. First, we only enrolled a small sample and performed a retrospective study in a single center. Second, we evaluated the efficacy of both treatments according to partial Mayo score without endoscopic assessment. Third, we could not monitor the trough level of IFX and the fecal calprotectin levels because monitoring these has not been approved by Japanese health insurance.

In conclusion, this study found that IFX and Tac have equivalent short-term efficacy for patients with moderate to severe UC. Although this study adjusted for background factors to reduce the influences of selection bias and potential confounding factors between each group using an IPTW technique, further randomized controlled trials are required to confirm the findings in our study.

Conflict of Interest Disclosure: The authors declare that there are no conflicts of interest.

Introducere. Atât infliximab (IFX) cât și tacrolimus (Tac) sunt eficiente pentru inducerea remisiunii clinice la pacienții cu colită ulcerativă (UC). Totuşi incă nu a fost realizat un studiu clinic randomizat care să adreseze eficacitatea IFX şi a Tac pentru pacienții cu colită ulcerativă moderat severă. Studiul şi-a propus să studieze retrospectiv eficiența IFX şi a Tac la pacienții cu colită ulcerativă moderat severă folosind o tehnică statistică (inverse probability of treatment weighting (IPTW)) pentru a ajusta după factorii de confuzie.

Materiale şi metode. Intre iulie 2009 şi martie 2016 au fost obținute date de la 122 pacienți cu colită ulcerativă moderat severă tratați fie cu $\operatorname{IFX}(n=58)$ or cu 
Tac $(n=64)$. Datele au fost obținute retrospectiv. Au fost comparate eficiențele pe termen scurt între grupul cu IFX şi Tac folosind IPTW.

Rezultate. Rata de remisie clinică la 14 săptămâni după inițierea tratamentului cu IFX a fost de 37.9\% (22/58) şi 50\% (32/64) in grupul Tac. Eficacitatea IFX şi Tac pentru remisie clinică nu a fost diferită în analiza univariată (Odds ratio [OR] 1.64, 95\% interval de incredere [CI] 0.80-3.37 $P=0.18$ ) şi nici în analiza multivariată $(O R=2.19,95 \%$ CI 0.85-5.61, P = 0.10). Factorii de confuzie au fost ajustați folosind tehica IPTW şi după realizarea acesteia eficiența Tac şi a IFX pentru remisie clinică nu a fost semnificativ statistic diferită între cele două grupuri $(O R=1.483 ; 95 \%$ CI, 0.581-3.785; $P=0.409)$.

Concluzii. IFX şi Tac au efect similar pe termen scurt în inducerea remisiei la pacienții cu colită ulcerativă.

* Correspondence to: HIROKAZU YAMAGAMI, Department of Gastroenterology, Osaka City University Graduate School of Medicine, 1-4-3 Asahimachi, Abeno-ku, Osaka 545-8585, Japan Phone: +81-6-6645-3811, Fax: +81-6-6645-3813 E-mail: yamagami@med.osaka-cu.ac.jp

\section{REFERENCES}

1. FAUBION WA, LOFTUS EV, HARMSEN WS, ZINSMEISTER AR, SANDBORN WJ. The natural history of corticosteroid therapy for inflammatory bowel disease: a population-based study. Gastroenterology. 2001; 121(2):255-60.

2. TURNER D, WALSH CM, STEINHART AH, GRIFFITHS AM. Response to corticosteroids in severe ulcerative colitis: A systematic review of the literature and a meta-regression. Clin Gastroenterol Hepatol. 2007; 5(1):103-10.

3. HINDRYCKX P, JAIRATH V, D'HAENS G. Acute severe ulcerative colitis: from pathophysiology to clinical management. Nat Rev Gastroenterol Hepatol. 2016; 13(11):654-64.

4. RUTGEERTS P, SANDBORN WJ, FEAGAN BG, REINISCH W, OLSON A, JOHANNS J et al. Infliximab for induction and maintenance therapy for ulcerative colitis. N Engl J Med. 2005; 353(23):2462-76.

5. D'HAENS G, LEMMENS L, GEBOES K, VANDEPUTTE L, VAN ACKER F, MORTELMANS L et al. Intravenous cyclosporine versus intravenous corticosteroids as single therapy for severe attacks of ulcerative colitis. Gastroenterology. 2001; 120(6):1323-9.

6. NARULA N, MARSHALL JK, COLOMBEL JF, LEONTIADIS GI, WILLIAMS JG, MUQTADIR Z et al. Systematic review and meta-analysis: Infliximab or Cyclosporine as rescue therapy in patients with severe ulcerative colitis refractory to steroids. Am J Gastroenterol. 2016; 111(4):477-91.

7. OGATA H, MATSUI T, NAKAMURA M, IIDA M, TAKAZOE M, SUZUKI Y et al. A randomised dose finding study of oral tacrolimus (FK506) therapy in refractory ulcerative colitis. Gut. 2006; 55(9):1255-62.

8. OGATA H, KATO J, HIRAI F, HIDA N, MATSUI T, MATSUMOTO T et al. Double-blind, placebo-controlled trial of oral tacrolimus (FK506) in the management of hospitalized patients with steroid-refractory ulcerative colitis. Inflamm Bowel Dis. 2012; 18(5):803-8.

9. YAMAMOTO T, SHIMOYAMA T, UMEGAE S, MATSUMOTO K. Tacrolimus vs. anti-tumour necrosis factor agents for moderately to severely active ulcerative colitis: a retrospective observational study. Aliment Pharmacol Ther. 2016; 43(6):705-16.

10. ENDO K, ONODERA M, SHIGA H, KUROHA M, KIMURA T, HIRAMOTO K et al. A comparison of short-and long-term therapeutic outcomes of Infliximab - versus Tacrolimus-based strategies for steroid-refractory ulcerative colitis. Gastroenterol Res Pract. 2016:11. 3162595.

11. NUKI Y, ESAKI M, ASANO K, MAEHATA Y, UMENO J, MORIYAMA T et al. Comparison of the therapeutic efficacy and safety between Tacrolimus and Infliximab for moderate-to-severe ulcerative colitis: a single center experience. Scand J Gastroenterol. 2016; 51(6):700-5.

12. LENNARD-JONES JE. Classification of inflammatory bowel disease. Scand J Gastroenterol Suppl. 1989; 170:2-6; discussion 16-9.

13. LEWIS JD, CHUAI S, NESSEL L, LICHTENSTEIN GR, ABERRA FN, ELLENBERG JH. Use of the noninvasive components of the Mayo score to assess clinical response in ulcerative colitis. Inflamm Bowel Dis. 2008;14(12):1660-6. doi:10.1002/ibd.20520.

14. SANDBORN WJ, COLOMBEL JF, D'HAENS G, VAN ASSCHE G, WOLF D, KRON M et al. One-year maintenance outcomes among patients with moderately-to-severely active ulcerative colitis who responded to induction therapy with adalimumab: subgroup analyses from ULTRA 2. Aliment Pharmacol Ther. 2013; 37(2):204-13. 
15. LAHARIE D, BOURREILLE A, BRANCHE J, ALLEZ M, BOUHNIK Y, FILIPPI J et al. Ciclosporin versus infliximab in patients with severe ulcerative colitis refractory to intravenous steroids: a parallel, open-label randomised controlled trial. Lancet. 2012; 380(9857):1909-15.

16. WILLIAMS JG, ALAM MF, ALRUBAIY L, ARNOTT I, CLEMENT C, COHEN D et al. Infliximab versus ciclosporin for steroid-resistant acute severe ulcerative colitis (CONSTRUCT): a mixed method, open-label, pragmatic randomised trial. Lancet Gastroenterol Hepatol. 2016; 1(1):15-24.

17. VOIOSU T, BENGUŞ A, BĂLĂNESCU P, DINU R, VOIOSU A, BĂICUŞ C et al. Rapid fecal calprotectin testing predicts mucosal healing better than $C$-reactive protein and Serum tumor necrosis factor $\alpha$ in patients with ulcerative colitis. Rom $\mathrm{J}$ Intern Med. 2015; 53(3):253-60.

18. DOTAN I, RON Y, YANAI H, BECKER S, FISHMAN S, YAHAV L et al. Patient factors that increase infliximab clearance and shorten half-life in inflammatory bowel disease: a population pharmacokinetic study. Inflamm Bowel Dis. 2014; 20(12):2247-59.

19. BRANDSE JF, MATHÔT RA, VAN DER KLEIJ D, RISPENS T, ASHRUF Y, JANSEN JM et al. Pharmacokinetic features and presence of antidrug antibodies associate with response to Infliximab induction therapy in patients with moderate to severe ulcerative colitis. Clin Gastroenterol Hepatol. 2016;14(2):251-8.e1-2.

Received January 25, 2017 